\title{
The Viewpoint of Primary School Teachers on the Reasons for the Low Level of Students in Mathematics in Iraq- the Province of Babylon as a Model
}

\author{
Oday Hatem Jalel* $\quad$ Hayder Hussein Jaddoa \\ Assistant teacher - General Directorate of Education, Babylon Governorate
}

\begin{abstract}
The aim of the research is to identify the teachers' views on the reasons for the students' low level in mathematics according to various variables, including gender, academic qualification, specialization, and experience.It was relied on a questionnaire prepared to measure the reasons for the low level of students in mathematics. It consisted of (28) paragraphs, each paragraph representing the possible reasons for this decline. The study was applied to a sample of (150) male and female teachers representing $65 \%$ of the original study population in a number of schools in Babylon Governorate - Iraq.
\end{abstract}

Keywords: Academic achievement , low achievement , primary school

DOI: $10.7176 / \mathrm{MTM} / 11-6-03$

Publication date: December $31^{\text {st }} 2021$

\section{1- Introduction}

The low academic level of students is one of the big and important problems that must be found appropriate solutions. It is a problem of dimensions, sometimes it is a educational problem and psychological and at other times it is a social problem that psychologists are concerned with in the first place and then educators, social workers and parents. It has attracted the attention of many educators, parents and students themselves, and their thinking as the main source of impeding growth and progress for a renewed life.

The problem of low achievement is one of the most important problems that hinder the modern school and prevent it from fulfilling its mission to the fullest extent. The problem is in almost every classroom, where there is a group of students who are unable to keep pace with the rest of the colleagues in collecting and absorbing the prescribed curriculum, and this group often turns into a source of rioting and disturbance, which may cause disruption of the educational process within the classroom or disruption of study in general within School (Haridy, 2003; Ali, 2001).

The teaching methods used for a long time were not concerned with developing the search for knowledge, nor were they concerned with employing school learning in practical life. This is because society, with all its capabilities and preparations, did not need more than that. Now that the priorities that appeared in the community and affected its preparations have changed, the interest in the learner has become commensurate with the changes that the world is witnessing today. Education in the current century is directed towards employing school learning in the areas of life and the use of information technology, and many goals that do not depend on indoctrination And conservation, but extends and deepens more in the processes of teaching and effective learning based on renewable educational theories, which requires educational institutions to redevelop their programs in order to meet the needs of modern life, and to keep pace with the rapidly changing scientific and technical developments, which require education of a new type in all stages and types of education (Al-Laqani and Al-Jamal, 2003).

One of the goals of education is to raise people who are able to think, research and solve the problems they face, hence the interest in developing higher-order thinking skills and the learner's mental abilities, and since mathematics curricula are one of the important areas in training students on different thinking patterns because of the advantages of mathematics that help in that Therefore, he made many conferences that discussed mathematics educators to emphasize in their recommendations the importance of mathematics and its education in order to achieve those goals (Ali, 2001).

In order to determine the students' levels in mathematics, the stakeholders use different means to know the extent to which students have mastered the mathematical concepts and skills, as one of those means was academic achievement, which is the test. The basis by which the students' acquisition of a specific content of mathematics is known. In addition to being the tool that determines the level of students within a particular group, and although achievement plays a major role in shaping and defining the learning process, there are other factors that influence and interfere in it, some of which are cognitive, and some are non-cognitive, such as motivation and temperament. Cognitive factors include: Mathematical ability that includes inferential ability, spatial ability, numerical ability, and others (Ali, 2001). Hence, the current study's interest in knowing the reasons behind the low achievement of primary school students in mathematics.

a- Research problem

The research problem revolves around studying the reasons for the low level of students in mathematics and the 
views of primary school teachers by studying a number of variables, including (gender, educational qualification, specialization, experience). Knowing the negative effects of low academic level on the educational system and society in general because it leads to academic failure and consequently dropping out.

To determine this problem, it was formulated in the form of a specific question as follows:

What are the views of primary school teachers on the reasons for the low level of students in mathematics in Babylon Governorate?

\section{b- The importance of research}

The importance of the research comes from a number of scientific and theoretical aspects, namely:

1- Identifying the reasons for low academic achievement in mathematics in the primary stage from the point of view of male and female teachers in the province of Babylon.

2- Providing those concerned with these matters with a descriptive survey on the causes of low achievement in mathematics in particular to address this problem and find what is necessary to deal with it.

3- This study is considered one of the descriptive sources that provide researchers and students with important information about primary school students who need to develop their skills in mathematics and do not have the ability to do so.

4- The results of this research can be used to develop the work of school counselors and supervisors and help them achieve educational goals through their cooperation with teachers.

c- Research Aims:

The research aims to:

1- Recognizing the viewpoint of the teachers of Babylon Governorate on the reasons for the low level of students' achievement in mathematics.

2- Recognizing the relative order of the reasons for low achievement in mathematics among primary school students from the point of view of teachers in the province of Babylon.

3- Knowing whether there are important differences between teachers' perspectives in analyzing the reasons for the low academic level in mathematics for students according to the variables that were mentioned previously in the primary schools of Babylon Governorate

d- Search determinants

1- Human determinants: Primary school teachers determined the results of this research in terms of estimating the reasons for students' low level of mathematics.

2- Spatial determinants: This research was conducted in government schools in Babylon Governorate.

3- Time limitations: This research was conducted in the first semester of the academic year 2018-2019

\section{Research method}

In this research, the descriptive analytical method was followed in order to identify the reasons for the low achievement of primary school students in mathematics from the teachers' point of view.

\section{The First Topic / theoretical framework}

The issue of poor achievement of students is considered one of the important and sensitive issues, because it relates to the future of this group and their social and professional life in the future, as well as their psychological stability. Some teachers believed that students' poor achievement in academic subjects was linked to stupidity and mental retardation, while the objective view of students' academic delay was based on understanding and analyzing all aspects related to the student and the educational process in order to identify the real causes of this delay. Some theoretical studies (Labeid, 2001; Shaheen, 2004) and (Youssef, 2005; Hassan, 2006) indicate several factors that are considered influencing the decline in general academic achievement, namely:

1- The disintegration of the family and its impact on children and their academic achievement

2- Causes specific to the student and include two types of disorders, namely, organic disorders and psychological disorders.

3- Low level of student intelligence, where school success is linked to the mental age of the student, and the student is often exposed to failure in achievement if he is asked to collect facts, information and skills above the level of his mental abilities

4- The general health status of the student: It is noticeable that the student who does not enjoy a high rate of health and physical fitness cannot focus his attention in his lessons for a long period of time, because he feels effort, fatigue and exhaustion for the least effort he makes, and therefore quickly becomes distracted, and loses the ability to follow the teacher In his explanation of the lesson, he did not understand anything. Consequently, he cannot perform homework or review previous lessons, and thus lags behind his colleagues who enjoy a high level of health in his achievement.

5- Emotional and social development disorder Pupils who live in unhealthy social environments are often exposed to disturbances in their emotional and social development.

As for mathematics, studies (Halil and Halhel, 2006; Youssef, 2005) indicated that students' weakness may 
be due in particular to the following reasons, whether these reasons are singular or combined, which are:

1- Changes in the educational curriculum: It is noted that changes in the educational curricula in general and the mathematics curriculum in particular affect immediately and directly the teaching process and consequently the achievement of students.

2- Teachers: Attention must be paid to raising the level of teachers and raising their capabilities, helping them to adapt to and keeping pace with the resulting changes, and providing them with the necessary tools to act well and deal with the new requirements.

3- Students: They are the main focus in the educational process. All programs and plans must take care of the student's comfort and well-being in order to prepare him for good citizenship and leadership in the future. We must pay attention to the fact that adults are the ones who decide the future goals from which the student can choose.

4- Parents: Being the main source of material, social and psychological support, they sometimes cannot bear the required burdens of their role.

5- Teaching environment and contents: Among the desired changes in the teaching environment, in teaching aids, means of illustration, and in learning centers.

6- The Ministry of Education: These changes oblige the Ministry of Education to support schools and teachers in many areas, including: counseling, completion courses, purchasing equipment, and others. Without substantive support, many difficulties will arise when trying to implement the new plan, and these changes will require huge financial costs.

The research community consisted of all mathematics teachers in the primary stage (from the first to the fourth grade in government schools in Babylon Governorate, and their number is (230) male and female teachers studying in (65) schools, including (31) schools for males, and (27) A school for girls, and (7) co-ed schools, and they are distributed according to the variables of gender, qualification and specialization, as shown in the following table:

Table No. (1)

Distribution of the research community according to gender, academic qualification and specialization variables

\begin{tabular}{|c|c|c|c|}
\hline Variable & The level & The number & Percentage \\
\hline \multirow{2}{*}{ Gender } & male & 110 & $47.8 \%$ \\
\cline { 2 - 4 } & female & 120 & $52.2 \%$ \\
\hline \multirow{2}{*}{$\begin{array}{c}\text { the scientific } \\
\text { qualification }\end{array}$} & diploma & 100 & $43.5 \%$ \\
\cline { 2 - 4 } & Bachelor & 130 & $56.5 \%$ \\
\hline Academic specialization & Mathematics & 160 & $69.6 \%$ \\
\cline { 2 - 4 } & other specialty & 70 & $30.4 \%$ \\
\hline
\end{tabular}

Source: Ministry of Education statistics for the academic year 2018-2019.

The research sample consisted of (150) male and female teachers of mathematics for the primary stage in government schools in Babylon Governorate, and they represent $(65 \%)$ of the original population of the study. Distributed according to the independent study variables, as shown in the following table:

Table No. (2)

Distribution of the research sample according to the independent research variables

\begin{tabular}{|c|c|c|c|}
\hline Variable & The level & The number & Percentage \\
\hline \multirow{2}{*}{ Gender } & male & 72 & $48 \%$ \\
\cline { 2 - 4 } & female & 78 & $52 \%$ \\
\hline \multirow{2}{*}{$\begin{array}{c}\text { the scientific } \\
\text { qualification }\end{array}$} & diploma & 65 & $43 \%$ \\
\cline { 2 - 4 } Academic specialization & Bachelor & 85 & $57 \%$ \\
\cline { 2 - 4 } & Mathematics & 104 & $69 \%$ \\
\hline \multirow{3}{*}{ Years of Experience } & other specialty & 45 & $31 \%$ \\
\cline { 2 - 4 } & less than 5 years & 70 & $46.7 \%$ \\
\cline { 2 - 4 } & $5-10$ years & 50 & $33.3 \%$ \\
\cline { 2 - 4 } & $10-15$ years & 18 & $8 \%$ \\
\hline
\end{tabular}

Source: Table prepared by the researcher.

A questionnaire was prepared for its adoption as a tool to measure the reasons for the low achievement of students in mathematics from the point of view of their teachers. The process of constructing this questionnaire went through the following procedural steps:

1- The selected sample of teachers was asked the following question (In your opinion, what are the most important reasons behind the low achievement of students in mathematics?)

2- After recording and analyzing teachers' responses, we have a number of reasons for weakness in mathematics, which are (37) reasons that were formulated and organized to represent the study tool in its 
initial form.

3- The items of this tool were also presented to a group of arbitrators, whose number amounted to (5), from university professors, to express their comments on the research tool and modify them.

4- Thus, the study tool in its final form includes (28) items, each of which represents a possible reason behind the students' low achievement in mathematics, for which the research sample is answered according to Likert scale (very large, large, medium, few, very few) and give scores according to the type of answer.

5- The stability of the current search tool was verified, as it adopted the method of internal consistency (Internal Consistency) using Cronbach's alpha equation(Cronbach Alpha) the value of the total stability coefficient of the instrument is $(0.87)$.

The second topic: statistical processing

The statistical package (SPSS) program was used to process the data obtained statistically by using the following descriptive and analytical statistical treatments:

1- Arithmetic averages, percentage and standard deviation.

2- T-test for independent operations

3- one-way analysis of variance (One Way A nova)

A number of results were reached by answering five questions that were asked to the research sample, which we will discuss and analyze successively

- What are the reasons for the low level of achievement of primary school students in mathematics?

To answer this question, the arithmetic means, standard deviations, and percentages of the research sample were calculated for each item of the tool. In order to interpret the results, the relative criterion for evaluating teachers' ratings was adopted, as shown in Table No. (3) as follows:

Table No. (3)

Arithmetic averages, standard deviations, percentages, and overall assessment of the reasons for students' low achievement in mathematics from the teachers' point of view, arranged in descending order according to their importance

\begin{tabular}{|c|c|c|c|c|c|c|}
\hline 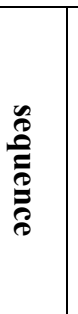 & 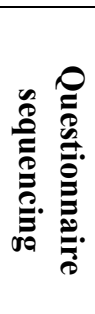 & Items & 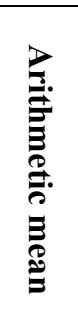 & 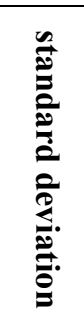 & 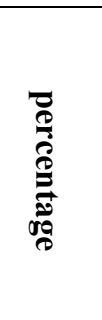 & Rating \\
\hline $1-$ & 4 & $\begin{array}{c}\text { Health weakness affects students' achievement in } \\
\text { mathematics }\end{array}$ & 4.32 & 0.88 & 86.40 & $\begin{array}{l}\text { very } \\
\text { big }\end{array}$ \\
\hline $2-$ & 3 & $\begin{array}{l}\text { Behavioral problems affect students' achievement } \\
\text { performance in mathematics }\end{array}$ & 4.25 & 0.91 & 85.07 & $\begin{array}{l}\text { very } \\
\text { big }\end{array}$ \\
\hline $3-$ & 1 & $\begin{array}{l}\text { Lack of self-interest in studying leads to a student's low level } \\
\text { in mathematics }\end{array}$ & 4.16 & 0.95 & 83.20 & $\begin{array}{l}\text { very } \\
\text { big }\end{array}$ \\
\hline $4-$ & 2 & $\begin{array}{c}\text { Not feeling attached to school leads to a lack of interest in } \\
\text { studying }\end{array}$ & 4.12 & 0.93 & 82.40 & $\begin{array}{l}\text { very } \\
\text { big }\end{array}$ \\
\hline $5-$ & 12 & $\begin{array}{l}\text { Teachers' unfamiliarity with modern educational and } \\
\text { psychological theories leads to poor performance of students }\end{array}$ & 4.11 & 0.84 & 82.13 & $\begin{array}{l}\text { very } \\
\text { big }\end{array}$ \\
\hline 6- & 11 & $\begin{array}{l}\text { Failure to use attractive teaching methods and methods } \\
\text { affects students' achievement in mathematics }\end{array}$ & 3.97 & 0.82 & 79.33 & Big \\
\hline $7-$ & 6 & $\begin{array}{l}\text { Lack of parental attention leads to low achievement of } \\
\text { students in the primary stage }\end{array}$ & 3.95 & 1.16 & 78.93 & Big \\
\hline $8-$ & 7 & $\begin{array}{c}\text { The low social status of the family leads to a low level of } \\
\text { students' achievement in mathematics }\end{array}$ & 3.89 & 1.08 & 77.73 & Big \\
\hline $9-$ & 9 & $\begin{array}{c}\text { The work of the father and mother negatively affects the } \\
\text { level of academic achievement of the student }\end{array}$ & 3.87 & 0.98 & 77.33 & Big \\
\hline 10 & 15 & Low teacher salaries lead to low student achievement & 3.80 & 1.06 & 76.00 & Big \\
\hline 11 & 24 & $\begin{array}{l}\text { Students passing through the lower grades without being able } \\
\text { to do mathematics }\end{array}$ & 3.79 & 1.23 & 75.87 & Big \\
\hline 12 & 10 & $\begin{array}{l}\text { Failure to take into account the technical foundations when } \\
\text { building the curriculum in mathematics leads to poor student } \\
\text { achievement in this subject }\end{array}$ & 3.77 & 0.97 & 75.33 & Big \\
\hline
\end{tabular}




\begin{tabular}{|c|c|c|c|c|c|c|}
\hline 13 & 5 & $\begin{array}{l}\text { The low educational qualification of the father and mother } \\
\text { affected the students' low achievement in mathematics }\end{array}$ & 3.75 & 1.18 & 74.93 & Big \\
\hline 14 & 27 & Teaching mathematics by non-specialized teachers & 3.69 & 1.294 & 73.87 & Big \\
\hline 15 & 28 & $\begin{array}{c}\text { Poor adaptation and harmony between students and teachers } \\
\text { leads to low achievement in mathematics }\end{array}$ & 3.68 & 1.18 & 73.60 & Big \\
\hline 16 & 26 & Inconsistency of mathematics concepts for the student's level & 3.66 & 1.07 & 73.20 & Big \\
\hline 17 & 8 & $\begin{array}{l}\text { The lack of cooperation of some parents with the school } \\
\text { administration and their neglect of the results of their } \\
\text { children has a major role in the low achievement of students }\end{array}$ & 3.59 & 1.17 & 71.73 & Big \\
\hline 18 & 13 & $\begin{array}{l}\text { Failure to take into account individual differences when } \\
\text { presenting topics within the curriculum leads to low student } \\
\text { achievement }\end{array}$ & 3.56 & 1.05 & 71.20 & Big \\
\hline 19 & 14 & $\begin{array}{l}\text { The use of the memorization method used in teaching leads } \\
\text { to low student achievement }\end{array}$ & 3.55 & 1.17 & 71.07 & Big \\
\hline 20 & 25 & $\begin{array}{l}\text { The teacher did not follow up on students' solving } \\
\text { worksheets and homework }\end{array}$ & 3.55 & 1.19 & 70.93 & Big \\
\hline 21 & 21 & $\begin{array}{l}\text { A student spending a long time in front of the TV and the } \\
\text { Internet affects his achievement }\end{array}$ & 3.49 & 1.29 & 69.87 & medium \\
\hline 22 & 23 & $\begin{array}{l}\text { Mathematics teachers' failure to enroll in the appropriate } \\
\text { training courses leads to a lower level of students' level }\end{array}$ & 3.46 & 1.29 & 69.20 & medium \\
\hline 23 & 19 & $\begin{array}{l}\text { Failure to enter kindergarten at pre-school age leads to low } \\
\text { achievement }\end{array}$ & 3.43 & 1.16 & 68.67 & medium \\
\hline 24 & 22 & $\begin{array}{l}\text { Teachers' unfamiliarity with modern educational and } \\
\text { psychological theories leads to poor performance of students }\end{array}$ & 3.35 & 1.25 & 66.93 & medium \\
\hline 25 & 20 & $\begin{array}{l}\text { Increasing the teacher's quota affects the low level of student } \\
\text { achievement }\end{array}$ & 3.33 & 1.13 & 66.53 & medium \\
\hline 26 & 17 & $\begin{array}{l}\text { The low social status of the family leads students to } \\
\text { disinterest in studying }\end{array}$ & 3.33 & 1.25 & 66.53 & medium \\
\hline 27 & 18 & $\begin{array}{c}\text { The lack of modern equipment and means leads to low } \\
\text { student achievement }\end{array}$ & 3.29 & 1.28 & 65.87 & medium \\
\hline 28 & 16 & Class overcrowding leads to lower student achievement & 3.29 & 1.30 & 65.87 & medium \\
\hline \multicolumn{3}{|r|}{ overall average } & 3.71 & 0.34 & 74.26 & Big \\
\hline
\end{tabular}

The previous table shows that the five most important reasons that lead to a low level of students' achievement in mathematics according to teachers' estimations were in descending order: health weakness affects students' achievement, behavioral problems affect students' achievement performance, and self-reluctance to study leads to low The student's level in mathematics, and the lack of a sense of belonging to the school leads to a lack of interest in studying, and the lack of knowledge of teachers in modern educational and psychological theories leads to poor performance of students. The arithmetic average on these items ranged between $(4.32$ in percentage $86.4 \%)$ and (4.11 in percentage $82.13 \%$ ) The relative evaluation of these items was at a very high level. While the results showed that the five least important reasons that lead to a low level of student achievement in mathematics according to teachers' estimates were in the following ascending order: overcrowding of classes with students leads to low student achievement, lack of modern equipment and means leads to low student achievement, and low social status The family drives students to disinterest in studying, and the high teacher's quota affects the low level of student achievement, and teachers' lack of knowledge of modern educational and psychological theories leads to poor performance of students. The arithmetic average on these items ranged between (3.29 in percentage $65.87 \%$ ) and (3.35 in percentage $66.93 \%$ ), where the relative evaluation of these items was at an average level.

The previous table also shows that the overall average of the reasons for the students' low achievement in mathematics from the teachers' point of view has reached (3.71), which is in a percentage equal to $(64.26 \%)$ and with an average evaluation. The researcher believes that this result is appropriate for the following reasons: the teacher's lack of specialization in mathematics affects the student's low level, and the teacher's failure to follow up on homework, and the teaching methods used by teachers, and its reliance on automatic memorization, leads to low student achievement, and lack of consideration Individual differences when presenting topics within the curriculum lead to low student achievement, negative attitudes towards mathematics and its teacher, and students' lack of basic arithmetic skills such as the multiplication table, addition, subtraction, and division.

- Are there statistically significant differences according to the gender variable in teachers' estimates of the reasons for the low level of achievement in mathematics among students?

To answer the above question, we calculated the standard deviation and the arithmetic mean of the answers we collected from the study sample by gender variable. The t-test for two independent groups was used to verify 
the significance of the differences between these averages, the results of which are shown in the following table:

Table No. (4)

The results of the t-test for the significance of the differences between the arithmetic averages depending on the gender variable

\begin{tabular}{|c|c|c|c|c|c|}
\hline $\begin{array}{c}\text { Variable } \\
\text { gender }\end{array}$ & number & $\begin{array}{c}\text { Arithmetic } \\
\text { mean }\end{array}$ & $\begin{array}{c}\text { standard } \\
\text { deviation }\end{array}$ & $\begin{array}{c}\text { Calculated (t) } \\
\text { value }\end{array}$ & $\begin{array}{c}\text { Connotation } \\
\text { level }\end{array}$ \\
\hline male & 72 & 3.74 & 0.35 & 2.75 & $0.032^{*}$ \\
\hline female & 78 & 3.48 & 0.33 & & \\
\hline
\end{tabular}

* Statistical function at the level of significance $(\alpha \leq 0.05)$

From observing the results that we obtained from the above table, we find that there are statistically significant differences according to the gender variable in the teachers' estimates to determine the reasons for the low achievement in mathematics in favor of male teachers, that is, the males showed higher scores compared to the female teachers, and this was evident from the difference in arithmetic averages.

This result appears realistic and consistent with the results of theoretical studies related to gender differences in learning different skills, as these studies in developmental psychology indicate that males are superior to females in their ability to learn arithmetic and engineering skills.

- Are there statistically significant differences according to the academic qualification variable in the assessments of Babylon Governorate teachers for the reasons for the low level of achievement in mathematics among students?

To answer the above question, we calculated the standard deviation and the arithmetic mean of the answers we collected from the study sample according to the educational qualification variable. The t-test for two independent groups was used to verify the significance of the differences between these averages, the results of which are shown in the following table:

Table No. (5)

The results of the t-test to indicate the differences between the arithmetic averages according to the educational qualification variable

\begin{tabular}{|c|c|c|c|c|c|}
\hline $\begin{array}{c}\text { Variable } \\
\text { Academic } \\
\text { qualification }\end{array}$ & number & $\begin{array}{c}\text { Arithmetic } \\
\text { mean }\end{array}$ & $\begin{array}{c}\text { standard } \\
\text { deviation }\end{array}$ & $\begin{array}{c}\text { Calculated (t) } \\
\text { value }\end{array}$ & $\begin{array}{c}\text { Connotation } \\
\text { level }\end{array}$ \\
\hline diploma & 100 & 3.75 & 0.32 & 1.26 & 0.079 \\
\hline Bachelor & 130 & 3.71 & 0.33 & & \\
\hline
\end{tabular}

The above table shows that there are no statistically significant results for the answers of the study sample according to the academic qualification variable, and this is what was shown by the results of the arithmetic averages. Any teachers' estimates in determining the reasons for the decline do not differ, whether they hold a diploma or a bachelor's degree.

From observing the results we obtained, we conclude that teachers who have experience and a scientific qualification close to mathematics, such as physics, have a reason for the absence of differences between the opinions of the study sample.

- Are there statistically significant differences according to the variable of academic specialization in the assessments of Babylon Governorate teachers for the reasons for the low level of achievement in mathematics among students?

To answer this question, the arithmetic averages and standard deviations of the responses of the teachers of the research sample were calculated to estimate the reasons for the low level of academic achievement according to the variable of academic specialization, and the t-test was used for two independent groups to verify the significance of the differences between these averages, the results of which are shown in the following table:

Table No. (6)

The results of the $(t)$ test to indicate the differences between the arithmetic averages according to the variable of academic specialization

\begin{tabular}{|c|c|c|c|c|c|}
\hline $\begin{array}{c}\text { Variable } \\
\text { Study } \\
\text { specialization }\end{array}$ & number & $\begin{array}{c}\text { Arithmetic } \\
\text { mean }\end{array}$ & $\begin{array}{c}\text { standard } \\
\text { deviation }\end{array}$ & $\begin{array}{c}\text { Calculated (t) } \\
\text { value }\end{array}$ & $\begin{array}{c}\text { Connotation } \\
\text { level }\end{array}$ \\
\hline diploma & 160 & 3.77 & 0.34 & 2.45 & $0.01^{*}$ \\
\hline Bachelor & 70 & 3.63 & 0.38 & & \\
\hline
\end{tabular}

* Statistical function at the level of significance $(\alpha \leq 0.05)$

By studying the results of the table above, we find that there are statistically significant differences in the responses of teachers, especially in the arithmetic average, in estimating the causes of low achievement for students according to the variable of academic specialization. Where teachers specializing in mathematics showed higher grades than other majors. 
It is not excluded that mathematics teachers are more able than others to understand and determine the reasons for the low level of students' achievement in mathematics, and this is a logical result.

- Are there statistically significant differences according to the variable years of experience in teachers' estimates of the reasons for the low level of achievement in mathematics among students?

To answer this question, the arithmetic averages and standard deviations of the responses of the teachers of the research sample were calculated to estimate the reasons for the low level of academic achievement among primary school students according to the variable years of experience, and it was as shown in the following table:

Table No. (7)

Arithmetic averages and standard deviations according to the variable years of experience

\begin{tabular}{|c|c|c|c|}
\hline $\begin{array}{c}\text { Variable } \\
\text { Years of Experience }\end{array}$ & number & Arithmetic mean & standard deviation \\
\hline less than 5 & 70 & 3.75 & 0.32 \\
\hline $5-10$ & 50 & 3.70 & 0.36 \\
\hline $11-15$ & 18 & 3.71 & 0.42 \\
\hline more than 15 & 12 & 3.72 & 0.33 \\
\hline total summation & 150 & 3.71 & 0.34 \\
\hline
\end{tabular}

The table shows that there are small differences between the arithmetic averages of the teachers' responses to estimate the reasons for the low level of achievement of primary school students in mathematics according to the variable years of experience for teachers.

Table No. (8)

The results of the one-way analysis of variance test for the significance of the differences between the arithmetic averages according to the variable years of experience

\begin{tabular}{|c|c|c|c|c|c|}
\hline Contrast source & $\begin{array}{c}\text { sum of } \\
\text { squares }\end{array}$ & $\begin{array}{c}\text { degrees of } \\
\text { freedom }\end{array}$ & $\begin{array}{c}\text { average } \\
\text { deviations }\end{array}$ & $\begin{array}{c}\text { Calculated (F) } \\
\text { value }\end{array}$ & $\begin{array}{c}\text { Connotation } \\
\text { level }\end{array}$ \\
\hline between groups & 0.295 & 3 & 0.098 & 0.770 & 0.51 \\
\hline within groups & 18.639 & 146 & 0.128 & & \\
\hline Total & $\mathbf{1 8 . 9 3 4}$ & $\mathbf{1 4 9}$ & & & \\
\hline
\end{tabular}

What is clear from the above table is that there are no statistically significant differences in the responses of the teachers of the research sample, especially in the arithmetic averages according to the variable years of experience, meaning that the teachers' opinions and estimates do not differ according to the years of experience. The reason may be that most teachers have long or close years of experience, in addition to the fact that teachers are subject to training and rehabilitation programs before and during service, which reduces the gap between them in terms of the level of experience.

\section{Conclusions and Recommendations}

\section{1- Conclusions}

The research showed the following results after analyzing and studying the data we obtained:

a) There are five important reasons for the low achievement of students in mathematics according to the teachers' ratings, which are as follows:

- Poor health status of the students.

- Some students may have behavioral problems.

- Weakness of students' desire and interest in studying.

- Lack of a sense of belonging to the school.

- Teachers' lack of knowledge of modern educational and psychological theories.

b) The study showed that there are other reasons for the low level of students in the study, but with a lower impact rate than the previous ones, which are (lack of modern educational means - overcrowding in the classroom - the social status of the family - the large number of classes for teachers - the lack of the necessary scientific disciplines).

c) There are statistically significant differences according to the gender variable between the levels of teacher evaluation for the reasons for the low level of students' achievement in mathematics.

d) There are statistically significant differences according to the academic specialization variable between the teachers' evaluation levels for the reasons for the low level of students' achievement in mathematics in favor of the mathematics major.

e) There are no statistically significant differences according to the educational qualification variable between the teachers' evaluation levels for the reasons for the low level of students' achievement in mathematics.

f) The variable of experience did not give a statistically significant difference. 


\section{Recommendations}

Finally, the following recommendations can be suggested:

a) Increasing attention to the physical, health and psychological health of the student so that he can focus during the study.

b) Working to provide the school atmosphere or environment in order to increase students' motivation and increase their level of school affiliation.

c) Teachers should use attractive teaching methods, methods and activities that motivate students to study and pay attention.

d) Increasing the attention of parents to the problems of their children and following up on their achievement first-hand.

e) Developing the skills of mathematics teachers by opening courses and workshops on the methods of teaching mathematics.

f) Coordination between the higher educational leadership, whether in the Ministry of Higher Education or universities, on the issue of continuous improvement and development of the education process in a way that keeps pace with modern changes and developments.

g) Benefiting from previous global experiences in all countries, which have proven to be highly successful in economic, educational and social growth.

h) Conducting continuous training courses for teachers on the processes of applying and implementing sports education skills at work and continuously monitoring their performance.

\section{References:}

1- Hassan, Mahmoud (2006). Special Mental Achievement Abilities in Measuring the Student's Intelligence and Mental Abilities Available on the Internet at (www.quran-radio.com).

2- Hlehel, Mahmoud and Halil, Houria (2006). Factors affecting the achievement of students' work in mathematics and methods for improvement, Al-Resala Journal, Academic Institute for the Preparation of Arab Teachers, No.14

3- Shaheen, Mohammed (2004). Academic retardation and its causes, available on the website (http://annajah.net/arabic).

4- Ali, Abdel Karim Hussein Mohamed (2001). Mathematical ability and its relationship to achievement among secondary school students in the Republic of Yemen: an unpublished master's thesis: University of Aden: Yemen.

5- Labyad, Raed (2001). Academic retardation and multiple causes are available on the website (http://forum.toleen.com).

6- Al-Laqani, Ahmed and Al-Jamal, Najah (2003). The extent to which students comprehend the experiences and the effectiveness of written tests in detecting this. Available online at the site (www.nouwasat.org).

7- Youssef, Ali (2005). Underachievement is a problem that must be solved. Available online to the site (www.khdoori.com).

8- Haridy, Adel Muhammad (2003). Individual differences in emotional intelligence. Journal of Arab Studies in Psychology, No.2.

9- Cross, Dionne. (2009)."Creating optimal mathematics learning environments: Combining argumentation and writing". Interntional Journal of Scince and Methematics Education, 7(5).

10- Gazeley, Louise \& Dunne, Mairead .(2008). "Teachers, Social Class and Underachievement". British Journal of Sociology of Education, 29(5) 